\title{
AN EVALUATION OF CLIMATE CHANGE FROM A LEGAL PERSPECTIVE OF TURKEY IN THE SCOPE OF INTERNATIONAL LAW
}

\author{
Alan Ilemin $\mathrm{N}^{*}$ \\ Department of Law, the Justice Vocational School, Kocaeli University, Turkey
}

\begin{abstract}
Climate change is a global emergency. Each country's efforts and responses to climate change are of significance individually. The dynamics behind their attitudes are needed to be understood to harmonize global response. Turkey is of a different legal approach than the international community generally. For instance, it is the only G20 country that is not a party to the Paris Agreement. Also, the legal perspective of Turkey is of particular significance for the European Union to achieve its targets. Thus, the question of international legal steps taken and the next steps by Turkey arises. To evaluate this situation, the legal frameworks are analyzed with specific reference to Turkey. It was found that Turkey has been demanding to be recognized as a developing country in the international climate instruments. Although Turkey put some afford to act against climate change, it was not seen as adequate by scientific reports. Also, international and regional human rights instruments have been invoked by individuals for the current policies of Turkey and legal proceedings were started. For an efficient response to climate change, key points regarding common but differentiated responsibilities, the relationships between international and national laws, and the importance of laws with comparing regulations and political instruments are addressed to see how these points can inform recommendations. It is concluded that the ratification of the Paris Agreement is required in the first place. Then, enriched legal perspective in international law, and new specific climate laws in national laws are a necessity to provide a meaningful legal response to this global threat. It is hoped that other legal systems may benefit from analyzing its legal perspective. Every country needs to contribute to the shared enterprise of combatting climate change if the future of humanity and the natural world is to be assured.
\end{abstract}

Keywords: Climate Change, Turkey, International Law, the Paris Agreement

\section{Introduction}

Climate change is a transboundary problem calling for global solidarity if the issue is effectively addressed and the effects mitigated. However, the international community is already far behind its commitments to combat climate change. Despite the undertaking by the signatories of the Paris Agreement (2015, art.2) to hold global warming below $2^{\circ} \mathrm{C}$, global temperatures have already risen almost $1.0^{\circ} \mathrm{C}$ in response to human activity (The Intergovernmental Panel on Climate Change [IPCC] 2018). Thus, the efforts to mitigate the effects of climate change are at present insufficient and global warming will increase by approximately $3.0^{\circ} \mathrm{C}$ by 2100 if the required steps are not taken (Climate Action Tracker [CAT] 2019, p.1). The recent Emissions Gap Report by the United Nations Environment Programme (UNEP) affirms that maintaining current policies will result in a global temperature increase of between $3.4^{\circ} \mathrm{C}$ and $3.7^{\circ} \mathrm{C}$ by 2100 (UNEP, 2019, p.5). 
The effects of climate change have been perceived each day. Extreme weather conditions, drought, floods, rising sea levels, and many others became the daily problems of our lives due to climate change. It affects the air we breathe, the water we drink, the food we eat, our health, and our lives. The last year, 2020, was one of the three warmest years on record, and the sea level has risen at a higher rate, according to the World Meteorological Organisation (WMO, 2020). The same report reveals that greenhouse gas emissions increased despite COVID-19. The way things are indicating that we do not have much time left. Under these circumstances, recently, the UN Secretary-General called all countries to declare global a state of climate emergency until the world has reached net-zero CO2 emissions (Harvey, 2020).

One of the main responses developed by States is the emerging legal frameworks at international, regional and domestic levels. The legal frameworks on climate change have been increasingly developed within the last two decades. The examples of such a movement are 2118 laws and policies (The Grantham Research Institute on Climate Change and the Environment, 2021) regarding climate change around the world, the European Commission's proposed first European Climate Law for implementing a European Green Deal (2020), and the entry into force of the Paris Agreement (2015). Within these global legal productions, each country's efforts and responses to climate change are of significance individually. Particularly the countries, which have a different approach towards climate change, can be examined. The dynamics behind their attitudes are needed to be understood to harmonize global response.

Turkey is of a different legal approach than the international community generally. Of the 197 countries included in the United Nations Framework Convention on Climate Change (the UNFCCC, 1992), 189 are party to the Paris Climate Agreement. Besides, Turkey is the only G20 country that is not a party to the Paris Agreement. Turkey signed the Paris Agreement on 22nd April 2016 but has not ratified, which means that Turkey does not have binding targets under the Agreement. The rationale behind this approach came from the previous international instruments that are the United Nations Framework Convention on Climate Change, a Kyoto Protocol, to the United Nations Framework Convention on Climate Change (the Kyoto Protocol, 1997). In the scope of all international instruments, as explained in the following part of this Paper, Turkey would like to be recognized as a developing country.

Turkey has argued that it did not contribute to the current level of greenhouse gases as a developing country. From scientific facts, indeed, Turkey was one of the lowest emitters among the Organisation for Economic Co-operation and Development (OECD) countries, according to the OECD data on air and greenhouse gases for the period between 2000 and 2018. Although Turkey has been responsible for fewer greenhouse gas emissions than the other OECD countries, the gap between the volume of emissions by Turkey and the other OECD countries has altered (OECD, 2012). The trend in Turkey's greenhouse gas emissions has been upward, representing a dramatic change, when evaluated alongside the data for the other OECD countries. This fact indicates the need for precautions to be taken now with an eye on future developments if a drastic increase in greenhouse gases is to be prevented. Hence, the question of what kind of international legal steps were taken in Turkey arises.

It must also be considered that a legal perspective of Turkey on climate change is of particular significance at present, given the European Commission's aim for Europe to become the world's first climate-neutral continent by 2050, as presented in the European Green Deal, and the fact that Turkish 
territory encompasses portions of South-Eastern Europe. For the achievement of this target, the level of implementation of laws in Turkey is needed to be considered. Herein, it must be noted that Turkey's legislative framework to tackle climate change has, in general, developed in the context of international concerns, in particular, the accession process for the European Union and the UNFCCC process (Republic of Turkey Ministry of Environment and Urbanization, 2018, p.76). Although climate change has tended to be viewed as a foreign policy issue in Turkey (Özışık, 2020, pp. 67, 75), the focus throughout this paper will be legal rather than political. Political dimensions will only be introduced when they are fundamental to understanding the legal perspective.

Thus, the international legal frameworks will be examined from the legal perspective of Turkey, the legal gaps determined, and suggestions offered for how these gaps might be plugged. First, Turkey's legal framework and perspective will be discussed under the scope of international law in the first section. This section will be divided into two parts: the situation before the Paris Agreement and the current situation under the Paris Agreement. The second chapter will introduce some key points of significance regarding common but differentiated responsibilities, the relationships between international and national laws, and the importance of laws with comparing regulations and political instruments in evaluating the legal aspect before conclusions are drawn in the final section.

\section{The main concern: Recognition as a Developing Country}

Climate change is a complex issue and requires a holistic approach involving many disciplines. For this reason, the climate change regime is intrinsically linked to other regimes in environmental law, such as the preservation of biodiversity, wetlands and the ozone layer and combating desertification. However, the instruments regarding these regimes will not be examined in this paper, and the focus will remain on the climate change regime. Thus three international instruments will be examined in the first part: The UNFCCC, the Kyoto Protocol, and the Paris Agreement.

Within all international legal developments related to climate change, the Paris Agreement is one of the revolutionary steps globally. However, as stated before, Turkey has not ratified the Agreement yet. Therefore, it must be considered that Turkey's legal perspective is strictly linked with the previous international instruments. Each development at the global level resulted in a unique approach by Turkey. In this part, thusly, the legal approach of Turkey will be divided into two categories in such a way as to be the situations before the Paris Agreement and the era of the Paris Agreement. The legal situation of Turkey could be better understood with this division. After this examination, the future direction needs to be assured.

\section{A. Before the Paris Agreement}

The establishment of a climate change regime for the first time at the global level was no easy task. In particular, the different needs and responsibilities of developed versus developing states, and the lack of a common position amongst these states had profound effects upon negotiations for a convention on climate change (Birnie, Boyle and Redgwell, 2009, p.357). This negotiation process was integrated into the Rio Conference in 1992, and the UNFCCC was the eventual result. The main objective of the UNFCCC is to stabilise greenhouse gas emissions at a level sufficient to prevent dangerous anthropogenic interference with the climate system. (It fails, however, to quantify what the level for stabilization might be. The UNFCCC of Article 2 merely states that 'such a level should be achieved within a time-frame sufficient to allow ecosystems to adapt naturally to climate change, to ensure that 
food production is not threatened and to enable economic development to proceed in a sustainable manner.)

The Convention entered into force on 21st March 1994, and 197 countries have ratified it, which indicates virtually universal acceptance by the international community. When the UNFCCC entered into force, Turkey was not the Party of the Convention. Since Parties to the UNFCCC are classified into three categories: Annex I countries (Annex I countries are industrialized and have additional obligations to reduce emissions of greenhouse gases to the level of 1990. See, art 4(2) (a) and (b)), Annex II countries (Annex II countries are required to provide financial resources and facilitate technology transfer to developing countries.), and all other countries (Other countries are mainly developing countries, and they are not under this sort of additional obligation.). Turkey was listed in the previous text of the UNFCCC in both Annexes I and Annex II as a member of the OECD. This entailed Turkey having a duty to reduce emissions of greenhouse gases in its capacity as an Annex I country and to provide financial resources and facilitate technology transfer to developing countries in its capacity as an Annex II country.

Under these obligations, Turkey did not ratify the UNFCCC. Turkey has tabled amendments to the lists in Annexes I and II on numerous occasions. Eventually, it was decided to remove Turkey from Annex II at the 7th Conference of the Parties (COP7), reflected in Decision 26/CP.7. The amendment of Annex II of the Convention was issued by the United Nations Secretary-General on 28 December 2001, and the amendment entered into force on 28 June 2002. Subsequently, Turkey became a party to the UNFCCC in 2004. But Turkey remained as an Annex I country in the fabric of the UNFCC that affected all the approaches of Turkey to international instruments in a later stage. Turkey has been asserted that the name of Turkey should not be included in Annex I as well.

Consequently, Turkey advocated for special circumstances comparing with other Annex I countries at COP 16 in Cancun. It was recorded that 'decision 26/CP.7 that amended the list in Annex II to the Convention by deleting the name of Turkey and decision 26/CP.7 that invited Parties to recognize the special circumstances of Turkey [...] place Turkey in a situation different from that of other Parties included in Annex I to the Convention.'(The UNFCCC COPs, 2011, p.24) Hence, it was recognised that Turkey's situation is different from that of the other Parties included in Annex I to the Convention. The COP 17 in Durban (The UNFCCC COPs, 2012, p.30) also accepted Turkey's special circumstances. Lastly, Turkey also proposed the amendment of the list of parties included in Annex I to the Convention and the removal of Turkey from Annex I to the Convention in 2018(The UNFCCC COPs, 2018). Turkey has been demanding to be a Non-Annex I Party instead of Annex I.

It must be noted that, as an Annex I country, Turkey is free to decide which national policies and measures on the mitigation of climate change (The UNFCCC, art 4(2)) will be implemented. It means that all States in Annex I have discretion for policies and mitigation. At the global level, this situation was discussed, and it was accepted that the UNFCCC could not give the adequate impetus to fight climate change. However, since it does not include any binding concrete reduction targets and its timescale for implementation remains weak (Birnie, Boyle and Redgwell, 2009, p.360). This situation was also accepted in the First Conference of the Parties in Berlin, hence negotiations for new, stronger obligations were started, which led to the Kyoto Protocol. 
The Kyoto Protocol is based on the UNFCCC in terms of structure (The UNFCCC and the Kyoto Protocol are both based on annexes and countries listed in Annex I and Annex B are quite similar.) and principles (The Kyoto Protocol is also based on the principle of the common but differentiated responsibility and respective capabilities.). However, although the UNFCCC does not include binding concrete reduction targets for greenhouse gases, binding emission reductions for industrialised countries are found in the Kyoto Protocol. In other words, the new commitments agreed in the Kyoto Protocol will not apply to developing countries. The industrialised countries and the European Union, as listed in Annex B of the Protocol, had binding emission targets for greenhouse gases listed in Annex A for the five year period 2008-2012 (The Kyoto Protocol, art. 3). The Parties do not have to implement these binding emission targets in their countries, and they may implement instead the emission reduction targets where the cost is less, under the scope of the 'flexibility mechanisms' (The flexibility mechanisms consist of the Clean Development Mechanism (art 12), Joint Implementation (art 6) and Emissions Trading (art 17)) recognised in the Protocol (Koivurova, 2014, p.166).

The entry into force of the Kyoto Protocol was delayed due to the ratification process (see, art 24). The Protocol was adopted on 11 December 1997; however, it only entered into force on 16 February 2005. Currently, there are 192 parties to the Protocol. At this stage, it should be noted that some large emitters are either not a party to the Protocol, such as the US, or do not have binding reduction targets, such as Brazil. In Turkey's situation, it ratified the Kyoto Protocol on 28 May 2009. However, Turkey was in a special situation in that Turkey was not a party to the UNFCCC when the Kyoto Protocol was adopted in 1997. Hence, Turkey was not included in Annex B of the Kyoto Protocol, meaning Turkey was the only Annex I country not under obligation to reduce greenhouse gases between 2008 and 2012.

Johanna and İlhami Alkan Olsson determined three central reasons (2012, pp. 14, 18) why Turkey was reluctant to ratify the Kyoto Protocol. First, it was felt that the economic and sectoral structure of the country were inadequate. Thus, it was feared that the Kyoto Protocol would impede the Turkish development economy. Second, it was believed that the cost of the treaty commitments would be high. Moreover, finally, the design of the treaty and its fairness were questioned by the government. Although such arguments were the main reasons underlying Turkish reluctance to ratify the Kyoto Protocol, the European Union accession process altered Turkey's position. In addition, the removal of Turkey from Annex II was a factor affecting the ratification of the Protocol.

\section{B. The Paris Agreement and the Current Efforts of Turkey}

The system provided by the Kyoto Protocol has been continued through Meetings of the Parties (MOPs) and Conferences of the Parties (COPs). The maintenance of the Kyoto Protocol after 2012 was highlighted in the Bali Road Map in 2007. However, although the Kyoto Protocol was adopted for the second commitment period, between 2013 and 2020, and with the Doha Amendment in 2012, it has yet to enter into force. Meanwhile, the requirement for a global response and a global climate change agreement has started to be discussed. One of the Bali Road Map objectives was the improvement of a treaty system for the reduction of emissions, allowing for a global response and global cooperation.

This objective guided the Copenhagen Conference in 2009. The resulting (non-binding) Copenhagen Accord, which consists of certain political measures to reduce emissions, was created to achieve these 
objectives. In this, however, it failed (Koivurova, 2014, p. 167). After the Copenhagen Conference, the Cancun Conference was held, and measures were taken towards a climate regime in 2010. For instance, a Green Climate fund was established. The Durban Conference followed it in 2011, where there was an agreement to an extension of the Kyoto Protocol and the conclusion of a global agreement in 2015. The international community has noted the challenge faced in keeping the increase of global temperature below 2 degrees Celsius, as stated at the Durban Conference (Koivurova, 2014, p. 202). The realisation of a need for a new global agreement on climate change eventually culminated in the Paris Agreement.

The Paris Agreement aims to enhance the implementation of the UNFCCC and strengthen the global response to climate change (art. 2). With this aim in mind, the general objective of the Agreement is to keep any increase in global temperature no more than an absolute maximum of 2 degrees Celsius above pre-industrial levels, and further, to aim to keep the increase to no more than 1.5 degrees Celsius (art 2(a)). It was adopted on 12 December 2015 and entered into force on 4 November 2016 with the signature and ratification of at least 55 countries, which are collectively responsible for 55\% of greenhouse gas emissions. So far, 189 parties of the 197 included in the scope of the UNFCCC have ratified the Agreement. Turkey signed the Paris Agreement on 22 April 2016. However, Turkey has not ratified it yet. Turkey is the only G20 country that is not a Party to the Paris Agreement.

The main issue of why Turkey has not ratified the Agreement is related to the UNFCCC. The differential treatment based on annexes under the UNFCCC and Kyoto Protocol has been removed by the Paris Agreement (The InforMEA Project, 2017, p. 26). However, the terminology of 'developed' and 'developing' countries has continued in use, although there is no definition for this terminology in the Agreement. Accordingly, the Annexes and Provisions of the UNFCCC impact how the Paris Agreement is interpreted. (The InforMEA Project, 2017, p. 26). Accordingly, the status of Turkey will be a developed country under the fabric of the Agreement as an Annex I country in the UNFCCC.

This distinction between developed and developing countries has a particular significance for the obligations of the Parties in the Agreement. For instance, developed countries should continue taking the lead in establishing emission reduction targets, whilst developing countries should maintain their mitigation efforts (art 4(4)). In accordance with the overall aim, support will be provided to developing countries (art 4(5)). Also, developed countries should provide financial assistance to developing countries for mitigation and adoption, as required to maintain their obligations under the UNFCCC (art 9(1)). Developing countries may provide or continue to provide such support on a voluntary basis (art 9(2)). Hence, these obligations for developed countries will be binding for Turkey after the ratification.

Nevertheless, merely signing the Agreement does not mean that Turkey does not have any commitments in the scope of International Law. One of the main obligations of the signatory State is not to render the treaty obligations meaningless (Öktem, 2014, p.461). Also, after the signature, mutual expectations between signatory states and Parties of the international agreement (Öktem, 2014 , p.504). In this era between signature and ratification according to these obligations, Turkey submitted its' Intended Nationally Determined Contributions (INDCs), which is required to determine whether the world achieves the long-term goals of the Paris Agreement. Turkey committed up to a 21 percent reduction in greenhouse gas emissions from the business as usual level by 2030 (Republic of Turkey INDCs). 
At this stage, it must be determined whether this kind of international commitment adequate to achieve the target of the Paris Agreement. It was assumed that Turkey would meet the targets for nationally determined contribution with the current policies in place, and its nationally determined contributions will be more than 15 percent lower than the target emission levels in the report of the UNEP in 2019 (UNEP, 2019, p.6). But, Turkey has not made any commitments in terms of its target for 2020. According to the report, Turkey needs to maintain its political commitment, and policies must also be supported with suitable legal instruments. Therefore, although Turkey could meet its' targets for nationally determined contribution, it must be considered whether the INDCs of Turkey are consistent with the aim of the Paris Agreement.

CAT sheds light on this situation. It highlighted that Turkey's INDCs target is critically insufficient. If most countries follow the approach of Turkey, global warming could be $3-4{ }^{\circ} \mathrm{C}$ (CAT, The Country Report: Summary, 2020). The target of Turkey as 21 percent reduction in greenhouse gas emissions from the business as usual level by 2030 means that $356 \%$ above 1990 by 2030 and $150 \%$ above 2010 by 2030 excluding Land Use, Land-Use Change and Forestry (LULUCF) (CAT, The Country Report: Summary, 2020). The publication implied that Turkey had made little progress in tackling climate change, and most importantly, Turkey has not ratified the Paris Agreement.

Similar evaluations are made by the European Union as well. The developments in Turkey's legislative frameworks are strictly linked with the accession process for the European Union. When the country reports (The reports were called progress reports till 2016; however, the name was changed as country reports afterwards). Of the European Union are examined, overall, there has been limited progress on the problem of climate change in Turkey within the last decade, with the Reports for 2017, 2018, 2019, and 2020 indicating that no progress was deemed to have occurred. The requirement for Turkish ratification of the Paris Agreement, awareness-raising at all levels, and strategies for mitigation and for adoption and codification in law to occur have been underlined several times in these Reports.

Furthermore, legal proceedings were started for Turkey's approach towards climate change. Human rights instruments have been used for this aim. First, 16 children from all over the world submitted a complaint to the Committee on the Rights of Child in 2019 (McIntyre, 2019). They claimed that 5 countries, including Turkey, violated their rights, such as the right to life, health, culture laid in the Convention on the Rights of the Child (1989). Second, six Portuguese youth filed a complaint against 33 countries, including Turkey, again to the European Court of Human Rights. In this application (Youth for Climate Justice v. Austria, et al., 2020) the evaluation of the CAT, which implied INDCs target is critically insufficient, was indicated. The applicants allege that these countries have fallen short of human rights obligations. The Court accepted the application on $30^{\text {th }}$ November 2020 and the responded States must respond to the application. The proceedings still continue in front of the Court.

\section{Evaluation: Key Legal Points and Recommendations}

Some key points must be explained for a proper evaluation of the legal perspective in Turkey. First, as the principle of common but differentiated responsibilities has been included in international instruments and Turkey has invoked it on several occasions, this principle will be discussed. Second, the relationship between national laws and international laws will be evaluated because Turkey has 
not yet to ratified the Paris Agreement. And finally, the linkage between laws and regulations will be highlighted as this shows the direction of future domestic laws on climate change.

\section{Common but differentiated responsibilities}

The Principle of Common but Differentiated Responsibility is based on an application of the principle of equity in the scope of international law. It has been recognised many times in international legal instruments (For instance, see the 'Rio Declaration principle 7; UNFCCC art.3 (1); Paris Agreement art.2 (2)) used in the climate change regime. If the principle is examined in terms of definition, it combines two aspects: common responsibility and differentiated responsibility. Common responsibility denotes that climate change is a common concern of people (See the UNFCCC preamble). Hence, all States have a legal interest and legal responsibility to prevent climate change and its effects.

On the other hand, differentiated responsibility considers many factors, including special needs and circumstances, future economic development of developing countries, and historic contributions to causing an environmental problem in determining the responsibility borne by the State (Sands, 2003, p. 287). Redistribution of social and environmental costs is required now due to the fact that social and environmental costs of developed-nation industrialisation were not factored into consideration in the past(Charles and Shelton, 2007, p.107). It can be asserted Turkey's special circumstances have already been recognised through COPs; however, its legal responsibility is ongoing as climate change is the common concern of people.

\section{National law vs. International law}

As climate change is a transboundary problem, encouraging solutions that are achieved through national laws alone entails disadvantages. As Birnie, Boyle, and Redgwell (2009, p. 304) explained, first, there may be no legal remedy or no effective remedy for transboundary problems at the national level. Second, even where adequate laws exist at the domestic level, problems of jurisdiction, the availability of remedies, and enforcement in transboundary cases may restrict the effectiveness of national laws. Hence, international laws are required for transboundary cases to the extent that international law prevents some or all of these situations at the domestic level, secures access to justice and ensures adequate national remedies.

Bearing in mind these explanations, it bears reiterating that Turkey does not have any concrete reduction targets within the current international legal framework. On the other hand, it is recognised that concrete reduction targets in a legally binding instrument are a better way to respond to global and transboundary environmental challenges, as was seen by the success of the Montreal Protocol on Substances that Deplete the Ozone Layer (1987) in fighting the depletion of the ozone layer. Hence, Turkey needs to ratify the Paris Agreement to fit into this beneficial framework of international laws. However, just as international laws are vital for a global response to climate change, international laws should be supported by national laws (Giddens, 2008, p.3).

\section{Laws vs. Regulations}

Domestic laws are important in combatting climate change and its effects insofar as efforts to prevent climate change call for an engagement at all levels. At the international level, the importance of 
domestic laws to address the adverse impacts of climate change and to take action to prevent adverse impacts has already been accepted (The United Nations General Assembly [UNGA], 2016, paras 10, $63,64,79,115)$. With this in mind, Turkey has taken initiatives and created legislative and political instruments concerned with the position of Turkey in relation to climate change. When Turkey's legislation on climate change is examined, it is seen to be based on general and relevant laws such as the Environmental Law (1983, Law No. 2872) and other regulations strongly linked to climate change. (See, The Regulation on the Monitoring of Greenhouse Gas Emissions, 2014; The Regulation on the Reduction of Ozone Layer Depleting Substances, 2017. In addition, some communiques can be found in terms of the implementation of the laws.). However, a special Climate Law is not found in Turkish domestic law. At this point, a new Climate Law might be discussed as a binding and more powerful instrument at the domestic level. It may also prevent the burden of complicated legislation and allow the implementation to remain the province of regulations. The content of a putative Climate Law calls for further research if the legislation is to achieve its proper purpose. In any case, a Climate Law should cover situations mandating urgent action.

In terms of regulations, particularly two regulations are significant regarding climate change in the domestic law of Turkey. First, the Regulation on the Monitoring of Greenhouse Gas Emissions (2014) focuses on monitoring gas emissions, reporting the monitored gas emissions, and verifying reports before submission to the related Ministry. Second, the Regulation on the Reduction of Ozone Layer Depleting Substances (2017) covers reporting information related to particular substances and informing the public. Both regulations are based on the Environmental Law, and they refer to it for the imposition of sanctions in the form of administrative fines in cases where the regulations are violated. However, these Regulations do not envisage preventive measures to reduce emissions, as are required for the legislation to be properly meaningful (Garrett (ed), 2019, p.185). Therefore, it must be highlighted again that a Climate Law could better serve for sanctions as well. Also, although regulations are prominent in the domestic law in Turkey, laws are of a stronger legal effect than regulations at the domestic level in light of the hierarchy of norms.

\section{Conclusion}

The scientific evidence indicates that the international community has failed in its commitments despite an evident increase in legal instruments covering climate change. If the required steps are not taken urgently, the results will be severe for all of us. The situation in Turkey is no exception. Despite the fact that is, generally speaking, the greenhouse gas emissions of Turkey are less than those of other OECD countries, the amount of greenhouse gas emissions has been increasing in recent years. Therefore, Turkey should take precautionary steps for the future, and a drastic increase in greenhouse gases must be prevented. This acceptance must be supported by legislation. At the same time, the maintenance of political commitments supported by legal instruments is required.

Although all international legal instruments of the climate change regime are interlinked and indispensable, the UNFCCC and the Kyoto Protocol failed to provide adequate impetus to mitigate the effects of climate change from the beginning. Therefore the creation of a new agreement and setting out of concrete targets for States became necessary. Hence, the Paris Agreement came about, which represented a revolutionary step in the global response to climate change. The ratification of the Paris Agreement is now a required action for Turkey. The Country Reports of the EU underlined this requirement. Also, the CAT found that the efforts of Turkey with INDCs are critically 
insufficient. The inadequate action towards climate change has resulted in human rights legal proceedings vis-à-vis Turkey. In the future, it can be expected more this kind of human rights applications.

As international law instruments recognise the principle of Common but Differentiated Responsibilities, evaluation of Turkey's particular situation is required to understand this principle's scope. Briefly, whilst common responsibility denotes that all States bear responsibility for climate change, differentiated responsibility requires consideration of special circumstances. Turkey's special circumstances have already been recognised at the global level. Nonetheless, Turkey remains responsible for acting in the face of this global threat. A response to climate change requires global solidarity as it is a transboundary problem. International laws are an assurance for a legal and effective remedy. They solve the problems of jurisdiction, the availability of remedies, and enforcement in transboundary cases. Hence international laws secure access to justice. Furthermore, the benefits of international instruments can be observed from the success of the Montreal Protocol. In accordance with these positive impacts of international instruments, the ratification of the Paris Agreement will have a positive effect on Turkey's legal framework.

When the domestic laws of Turkey are examined, it is seen that regulations are particularly prominent. These regulations are important for implementation, but they should also include preventive measures. In addition, they are based on the Environmental Law, which is a general law. On the other hand, specific climate laws cannot be found at the domestic level. Therefore, there might be a future for a Climate Law; but, it requires further research to inform the content, and a comparative study would be helpful to ensure a successful result. In every case, new legal instruments should include ways to undertake urgent action.

Thus, Turkey's first priority should be the ratification of the Paris Agreement. As domestic laws should support international instruments, the second priority should be to consider specific domestic laws. However, an implementation may be able to remain with the regulations and political instruments. It must be considered that the political instruments are not binding, even though Turkey has had a range of political instruments. Political instruments and regulations are inadequate to address this urgent global threat. In other words, an enriched legal perspective is a necessity to respond to this global threat, and this must be at both the international and national levels. This legal response must be supported in such a way as to recognise the scientific understanding of nature and provide for a concerted response by everyone to ensure a better future for everyone.

\section{References}

Birnie P., Boyle A. And Redgwell C. (2009). International Law and the Environment. Oxford, Oxford University Press

Charles A. And Shelton D. (2007). Guide to International Environmental Law. Leiden, BRILL.

Climate Action Tracker (CAT) (2019). Scaling up climate action: Key opportunities for transitioning to a zero-emissions society: Executive Summary -CAT Scaling up Climate Action series: Turkey. [online]. Retrieved from: https://climateactiontracker.org/publications/scalingupturkey/

Climate Action Tracker (CAT)(2020). the Country Summary: Turkey. [online]. Retrieved from https://climateactiontracker.org/countries/turkey/

Convention on the Rights of the Child (CRC) 1989, adopted 20 November 1989, entered into force 2 September 1990. 
Giddens A. (2008). the Politics of Climate Change: National Responses to the Challenge of Global Warming, Policy Network Paper.

Harvey F. (2020, December 12). UN secretary general urges all countries to declare climate emergencies' The Guardian [online], Retrieved from: https://www.theguardian.com/environment/2020/dec/12/un-secretary-general-all-countries-declareclimate-emergencies-antonio-guterres-climate-ambition-

summit\#: :text=Governments $\% 20$ around $\% 20$ the $\% 20$ world $\% 20$ should,a $\% 20$ summit $\% 20$ of $\% 20$ world \%20leaders.

Hergüner Ü. et al.(2019). Chapter 15: Turkey. In: The Environment and Climate Change Law Review edited by Theodore L. Garrett. London, The Law Reviews 2019.

Koivurova T.(2014). Introduction to International Environmental Law. New York, Routledge.

Kyoto Protocol to the United Nations Framework Convention on Climate Change (the Kyoto Protocol) 1997, adopted 11 December 1997, entered into force 16 February 2005.

Mcintyre, J. (2019, September 25). With 15 other children, Greta Thunberg has filed a UN complaint against 5 countries. Here's what it'll achieve. The Conservation [online], Retrieved from: https://theconversation.com/with-15-other-children-greta-thunberg-has-filed-a-un-complaint-against-

5-countries-heres-what-itll-achieve-124090

Montreal Protocol on Substances that Deplete the Ozone Layer, 1987, adopted 16 September 1987, entered into force 1 January 1989.

Olsson J.A. And Olsson İ.A. (2012). Turkey's Signature of the Kyoto Protocol. Ístanbul Üniversitesi Siyasal Bilgiler Fakültesi Dergisi, 47, 1-30

Organization for Economic Co-operation and Development (OECD) (2000-2018). Air and GHG emissions 2000-2018. [online]. Retrieved from: https://climate-laws.org/legislation_and_policies.

Organization for Economic Co-operation and Development (OECD) (2012). Compare your country

Home Climate Change Mitigation Policies. [online]. Retrieved from: https://www.compareyourcountry.org/climate-policies?cr=oecd\&lg=en\&page=1\&visited=1 .

Öktem E. (2014).Uluslararası Andlaşmanın İmza İle Onay Arasındaki Hukuki Rejimi. Galatasaray Üniversitesi Hukuk Fakültesi Dergisi - Doç. Dr. Melike Batur Yamaner'in Anısına Armağan Cilt I, 79(58), 461-504.

Özişik F.U. (2020). Climate Change Policy in Turkey: A Perspective of Analysis through Historical Development. International Negotiations and Administrative Obstacles. Marmara University Journal of Political Science, 8(1), 66-96.

Republic of Turkey INDCs from https://www4.unfccc.int/sites/submissions/INDC/Published\%20Documents/Turkey/1/The_INDC_of_ TURKEY_v.15.19.30.pdf [online].

Republic of Turkey Ministry of Environment and Urbanization, (2018). Seventh National Communication of Turkey under the UNFCCC. [online]. Retrieved from https://unfccc.int/sites/default/files/resource/496715_Turkey-NC7-1-

7th\%20National\%20Communication\%20of\%20Turkey.pdf>

Rio Declaration on Environment and Development' adopted at the 'United Nations Conference on Environment and Development' (Rio de Janeiro 1992) UN Doc A/CONF.151/26/Vol. I

Sands P., 2003, Principles of International Environmental Law. Cambridge, Cambridge University Press.

The Environmental Law, 1983, Law No. 2872.

The Grantham Research Institute on Climate Change and the Environment,, (2021). 10 March [online]. Retrieved from: https://climate-laws.org/legislation_and_policies . 
The InforMEA Project, (2017). Climate Change International Legal Regime [online]. Retrieved from https://unccelearn.org/pluginfile.php/196738/mod_resource/content/2/InforMEA_Climate\%20Change \%20Legal\%20Regime_Lessons\%20Bundle.pdf

The Intergovernmental Panel on Climate Change (IPCC), (2018). Special Report: Global Warming of $1.5^{\circ} \mathrm{C}$, Summary for Policymakers.

The Paris Agreement, 2015, adopted 12 December 2015, entered into force 4 November 2016.

The Regulation on the Monitoring of Greenhouse Gas Emissions, 2014, No. 29003.

The Regulation on the Reduction of Ozone Layer Depleting Substances, 2017, No. 3003.

The UNFCCC Conference of the Parties, (2011). Report of the Conference of the Parties on its sixteenth session: Part Two: Action taken by the Conference of the Parties at its sixteenth session, held in Cancun from 29 November to 10 December 2010' FCCC/CP/2010/7/Add.1 p.24

The UNFCCC Conference of the Parties, (2012). Report of the Conference of the Parties on its seventeenth session: Part Two: Action taken by the Conference of the Parties at its seventeenth session, held in Durban from 28 November to 11 December 2011, FCCC/CP/2011/9/Add.1 p.30

The UNFCCC Conference of the Parties, (2018). Proposal from Turkey to amend the list of Parties included in Annex I to the Convention, FCCC/CP/2018/INF.2.

The United Nations Framework Convention on Climate Change (the UNFCCC), 1992, adopted 9 May 1992, entered into force 21 March 1994.

The United Nations General Assembly [UNGA], 'Implementation of the outcomes of the United Nations Conferences on Human Settlements and on Housing and Sustainable Urban Development and strengthening of the United Nations Human Settlements Programme (UN-Habitat)' (New Urban Agenda) (21 November 2016) UN Doc. A/71/L.23

United Nations Environment Programme (UNEP), (2019). Emissions Gap Report 2019 Executive Summary.

United Nations Environment Programme (UNEP), (2019). Lessons from a decade of emissions gap assessments: summary.

World Meteorological Organization (WMO), (2020). Provisional Report on the State of the Global Climate 2020.

Youth for Climate Justice v. Austria, et al. [2020] ECtHR Request No. 39371/20 